\title{
XLVII. Reply to the observations of M. Pierre, on the proportion of water in the magnesian sulphates and double sulphates
}

\section{Thomas Graham Esq. F.R.S.}

To cite this article: Thomas Graham Esq. F.R.S. (1846) XLVII. Reply to the observations of M. Pierre, on the proportion of water in the magnesian sulphates and double sulphates, Philosophical Magazine Series 3, 28:187, 289-291, DOI: 10.1080/14786444608645084

To link to this article: http://dx.doi.org/10.1080/14786444608645084

冓 Published online: 30 Apr 2009.

Submit your article to this journal $₫$

ЏII Article views: 2

Q View related articles $₫$ 
for different things. For example, the original English sense of the word square applies to an angle, not a figure; a right angle is a square corner; and to this day the carpenter's right angle is called a square. But I could name half-n-dozen writers of the end of the sixteenth century who use the two spellings square and squire, the former in the modern sense, the latter for the carpenter's instrument.

XLVII. Reply to the Observations of M. Pierre, on the Proportion of Water in the Magnesian Sulphates and Double Sulphates. By Thomas Graham, Esq., F.R.S.*

I $\mathbf{N}$ a late number of the Annales de Chimie, a paper by $\mathbf{M}$. 1 Isidore Pierre appears, On the Double Salts formed by the Oxides of the Magnesian Group, of which an abstract is also given in the March Number of the Philosophical Magazine, containing statements which demand some remark from myself. It presents new analyses of the sulphate of magnesia and potash, and other double sulphates of the same type, from which the author infers that these well-known double salts possess seven atoms of water crystallization, and not six atoms, as resulted from my own analyses and the analyses of all other chemists who have of late years examined these salts. The double salts in question are thus made by $M$. Pierre to have the same proportion of water as sulphate of magnesia itself; while the latter salt, also, is not found to retain its seventh atom of water more strongly than the other six, but to become anhydrous at $212^{\circ}$, or a few degrees above that temperature, in a current of dry air. The author then infers that his results are subversive of the theory which was originally published by myself, of the constitution of the magnesian sulphates, and to which I still adhere, namely that they contain an atom of water strongly attached and not easily expelled by heat, but readily replaced by an alkaline sulphate, with formation of a double salt.

Although confident of the accuracy of the analyses thus impugned, I considered it due to $M$. Pierre, who, although a young chemist, has afforded every evidence of habitual care and accuracy in another experimental inquiry of importance, to repeat my experiments.

Of the double sulphate of zinc and potash, 31.46 grains by drying at $212^{\circ}$ for several days, lost 7.75 grains of water; and by fusion at a heat verging on redness, 0.09 grain of water additional, making the whole loss $7 \cdot 83$ grains. Hence the composition of the salt with reference to water is as follows:

- Communicated by the Author.

Phil.Mag. S. 3. Vol.28. No.187, April 1846. X 


\begin{tabular}{|c|c|c|c|}
\hline \multirow[t]{2}{*}{$\begin{array}{l}\text { Water } \\
\text { Sulphate of zinc and potash }\end{array}$} & $\begin{array}{l}\text { Experiment. } \\
24 \cdot 89 \\
75 \cdot 11\end{array}$ & $\begin{array}{c}\text { Theory of } \\
6 \mathrm{HO} . \\
24.03 \\
75.97\end{array}$ & $\begin{array}{c}\text { Theory of } \\
\text { 7HO(Pierre) } \\
27 \cdot 32 \\
72.68\end{array}$ \\
\hline & $100^{\circ}$ & $\overline{100^{\circ}}$ & $100^{\circ}$ \\
\hline
\end{tabular}

The experiment obviously indicates six and not seven equivalents of water. The slight excess of 0.86 per cent. of water is not more than is usually found in crystallized salts, arising from the difficulty of divesting them entirely of water mechanically interposed between the plates of the crystals. The peculiarly high disposition of this particular class of salts to retain mechanical water, has been noted by Mitscherlich, myself, and almost every one else who has made them the subject of investigation. It has probably been the cause of the error into which M. Pierre has fallen, in over-estimating their proportion of water.

Although it is scarcely necessary to extend the inquiry to the other double salts of the class, which being isomorphous with the last have necessarily the same proportion of water, still I may be allowed to avail myself of a series of five analyses of the double sulphate of copper and potash lately executed in the laboratory of my friend Prof. Fownes, and which he has kindly communicated to me.

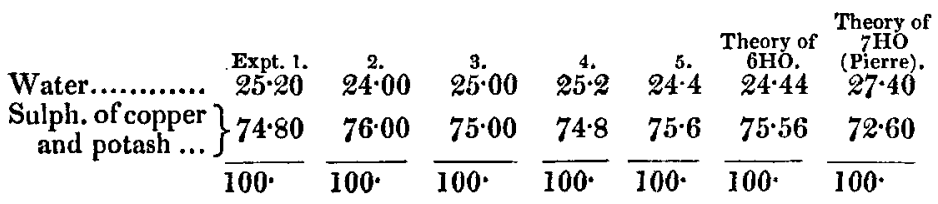

These experiments all concur in proving that six equivalents is the proportion of water in the double sulphate of copper and potash, and not seven equivalents.

Although M. Pierre gives seven atoms of water to the double sulphate of magnesia and potash, he adds, near the end of his paper, as if to qualify the statement, that when he communicated his results to M. Balard, that chemist informed him that the double sulphate of magnesia and potash contained no more than six equivalents of water, and was therefore consistent with the views of $\mathrm{Mr}$. Graham.

With reference to the single atom of water strongly retained by the magnesian sulphates, an experiment was made on sulphate of zinc. The crystallized salt dried for several days at $212^{\circ}$, in the same circumstances as those in which the double sulphate of zinc and potash became anhydrous, still retained water. The heat being continued for three or four days after 
the salt ceased to lose weight, it was thereafter found to consist of-

\begin{tabular}{|c|c|c|c|}
\hline \multirow[b]{2}{*}{ Sulphate of zinc } & \multicolumn{2}{|c|}{ Experiment. } & \multirow{2}{*}{$\begin{array}{l}\text { With one equivalent of } \\
\text { water. } \\
90.0 \hat{S}\end{array}$} \\
\hline & $20 \cdot 42$ & $89 \cdot 20$ & \\
\hline & $2 \cdot 46$ & $10 \cdot 75$ & $\mathbf{9 \cdot 9 7}$ \\
\hline & $22 \cdot 88$ & $100^{\circ}$ & $100^{\circ}$ \\
\hline
\end{tabular}

It is sufficiently evident, therefore, that sulphate of zinc, which is admitted by $M$. Pierre to contain seven equivalents of water, retains one equivalent of water by a stronger affinity than the other six, contrary to his observation; while, moreover, this strongly retained atom of water is absent in the double sulphate of zinc and potash, the last containing only six atoms of water - the experimental data on which the view of the constitution of these salts controverted by that chemist is founded.

XLVIII. On the Cohesion of Liquids and their Adhesion to Solid Bodies. By M. F. Donny, Agrégé à l'Université de Gand, Préparateur du Cours de Chimie.

To the Editors of the Philosophical Magazine and Journal. Gentremen,

THE twenty-sixth volume of your valuable Magazine 1 (p. 54.1) contains an account of two communications made by Prof. Henry to the American Philosophical Society, on the 5th of April and 17th of May 1844, both relative to the cohesion of liquids.

I have been investigating the same subject from the beginning of 184.1 to the end of 184.3 , when $I$ gave a full description of my experiments on cohesion and adhesion in a written communication addressed to the Académie Royale de Bruxelles. The reception of this memoir is recorded in the Bulletin de la Séance du 2 Décembre 1843 (tome x. p. 457), and the memoir itself is printed in the Mémoires Couronnées et des Savants Etrangers, tome xvii. I beg leave to direct your attention to the contents of this communication.

Having discovered, in 1841, as Prof. Henry did in 1844, that the cohesion of liquids is a powerful attraction, entirely misrepresented in the works on natural philosophy, I endeavoured to find out the cause of this misrepresentation. With this object I constructed a very simple instrument, which enabled me to observe accurately how the separation of water from water is effected, in the well-known experiment of a X 2 